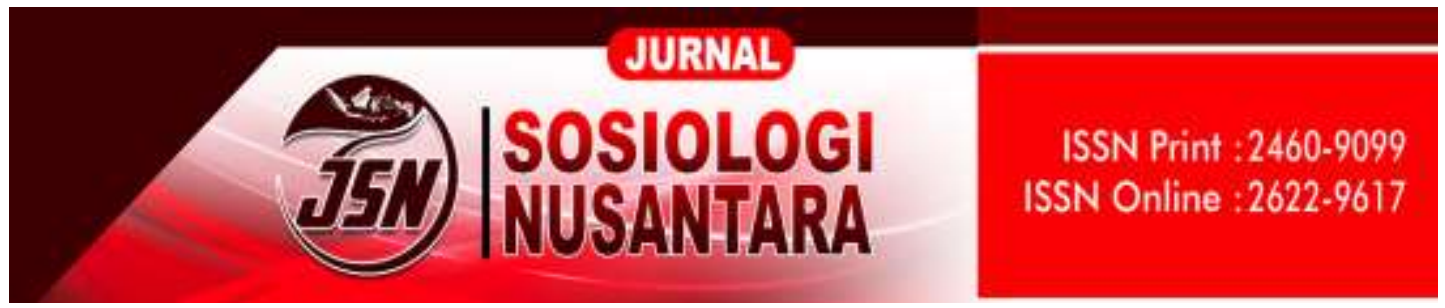

\title{
KETERLIBATAN MASYARAKAT LOKAL DALAM RESTORASI KAWASAN PASCA TAMBANG TIMAH OLEH PT. REFINED BANGKA TIN DI DESA PENYAMUN KABUPATEN BANGKA
}

\section{LOCAL COMMUNITY INVOLVEMENT IN THE RESTORATION OF THE POST TAMBANG AREA BY PT. REFINED BANGKA TIN IN PENYAMUN VILLAGE, BANGKA DISTRICT}

\author{
Alfin Dwi Rahmawan \\ Alfindwirahmawan98@gmail.com \\ Program Studi Sosiologi, Fakultas Ilmu Sosial dan Politik Universitas Bangka Belitung
}

\begin{abstract}
Abstrak
Restorasi merupakan upaya pemulihan kembali kawasan akibat kegiatan pertambangan agar dapat berfungsi kembali. Berdasarkan Peraturan Pemerintah (PP) No. 78 tahun 2010 tentang reklamasi dan pasca tambang bahwa pemegang izin usaha pertambangan harus melakukan reklamasi atas lahan yang dieksploitasi. Salah satu daerah yang dilakukan reklamasi adalah lahan bekas Tambang Inkonvensional (TI) di Desa Penyamun, Kecamatan Pemali, Kabupaten Bangka. Reklamasi ini dilakukan oleh PT. Refined Bangka Tin (RBT). Penelitian ini bertujuan untuk melihat pengelolaan reklamasi oleh PT. Refined Bangka Tin dan bagaimana sikap dan juga keterlibatan masyarakat lokal dalam proses reklamasi tersebut. Untuk menganalisis penelitian ini digunakan perspektif etika lingkungan dan juga restorasi ekologi. Metode penelitian yang digunakan adalah kualitatif deskriptif. Teknik pengumpulan data yang digunakan adalah dengan observasi, hasil wawancara, studi kepustakaan dan Focus Group Discussion (FGD). Hasil dari penelitian ini menunjukkan bahwa proses restorasi dilakukan dengan cara memanfaatkan lahan pasca tambang sebagai lahan pertanian yang bernilai ekonomis melalui program lingkungan hijau sehat (Green For Good), yang bertujuan menciptakan lanskip ekowisata yang dikelola dari masyarakat melalui koperasi penyamun lestari dan juga dalam proses pemulihan
\end{abstract}


Keterlibatan Masyarakat Lokal Dalam Restorasi Kawasan Pasca Tambang Timah .....

lahan melibatkan masyarakat lokal dengan memberikan peluang kepada masyarakat lokal untuk melakukan aktivitas menanam dan budidaya ikan di lahan reklamasi.

Kata Kunci : Masyarakat Lokal, PT.RBT, Restorasi

\begin{abstract}
Restoration can be defined as an effort to re-recovery the area of mining activities in order to be re-functioning. Based on Government Regulation (PP) No. 78/2010 concerning reclamation and post mining stated that the permit holders of mining business obligate to carry out the reclamation of exploited land. One of the reclaimed areas is the used land of unconventional mining (it is called TI in Indonesian) in Penyamun village, Pemali district, Bangka regency. This reclamation was carried out by PT. Refined Bangka Tin (RBT). This research aimed to examine the management of reclamation issued by PT. Refined Bangka Tin and also the manner and the involvement of the local societies in the reclamation process. To analyze this research, Enviromental Ethics Perspective and ecology restoration were used in this research. The qualitative descriptive used as the methodology through this research. The techniques of data collection are Observation, the results of interview, literature review, and focus group discussion. The result of this research showed that the process of restoration was conducted by utilizing the ex-mining land as the economical agricultural land through the program of healthy green environment (Green for good). This program intends to create the landscape of eco tourism managed by the local societies through Penyamun Lestari Cooperative. In addition, the process of land recovery involves the local community by giving opportunity to them to do the cultivation activity and fish farming in the reclamation area.
\end{abstract}

Keywords : Local Community, PT. RBT, Restorasi

\title{
PENDAHULUAN
}

Indonesia merupakan negara yang terdiri dari banyak pulau dan memiliki potensi sumber daya alam yang begitu melimpah. Hasil laut, hutan, dan buminya mengandung nilai yang sangat tinggi. Tidak sedikit masyarakat Indonesia sejak dulunya bergantung dengan kakayaan alam yang dimiliki untuk bertahan hidup. Kekayaan alam Indonesia bukan hanya laut dan hutannya saja, tetapi jauh di dalam perut bumi Indonesia menyimpan kekayaan alam yang dapat menompang perekonomian dan memiliki nilai ekonomis yang tinggi. Kekayaan alam yang 
terkandung dari dalam perut bumi tersebut terdiri dari emas, timah, minyak, batu bara, nikel, dan lain sebagainya.

Kekayaan alam tersebut menjadikan Indonesia memiliki lahan pertambangan yang tersebar di Indonesia, tak terkecuali sumber daya alam berupa timah yang juga menjadi salah satu negara pemasok timah terbesar di dunia. Cadangan timah ini tersebar di Indonesia yang memiliki bentang wilayah sejauh 800 kilometer yang disebut dengan The Indonesian Tin Belt (Sabuk Timah Indonesia) dan juga menjadi bagian Southeast Asia Tin Belt (sabuk Timah Asia Tenggara) yang membentang sejauh kurang lebih 3.000 kilometer dari daratan Asia ke arah Thailand, Semenanjung Malaysia hingga Indonesia (Harahap, 2016).

Salah satu kekayaan timah yang melimpah terdapat di daerah Kepulauan Bangka Belitung. Sejak dulu Pulau Bangka Belitung menjadi tempat penghasil timah terbesar, bahkan di dunia. Pada masa pra kemerdekaan, pengelolaan timah yang ada di Bangka Belitung dikelola oleh pemerintahan kolonial. Pada tahun 1816 penambangan timah di Bangka dikuasai oleh pemerintah Belanda dari Kerajaan Sriwijaya dan diberi nama "Bangka Tin Winning Bedrijf" disingkat B.T.W. Setelah Jepang berkuasa, mereka menunjuk Mitsubishi Kagyo Kaisha untuk mengusahakan tambang-tambang di Bangka, Belitung, dan Singkep, dan dilakukan di bawah kekuasaan militer Jepang (Bustami Rahman, Dwi Haryadi, 2011).

Bangka Belitung yang masuk ke dalam jalur lintasan timah terjaya di dunia atau disebut dengan jalur orogenese menjadikannya tempat penambangan terbuka. Banyak sekali daerah-daerah yang menjadi galian timah yang tersebar di antara kedua pulau utama, yakni Bangka dan Belitung. Dari sekian banyak tempat penambangan timah di Bangka Belitung terdapat satu Desa di Kabupaten Bangka Kecamatan Pemali yaitu Desa Penyamun yang juga sebaagai tempat penambangan timah yang cukup besar di Bangka. Sejak tahun 2002 lahan di Desa Penyamun mulai dibebaskan dari masalah Tambang Inkonvensional (TI), dan pada tahun 2008 lahan pertambangan mulai dikosongkan. Namun aktivitas pertambangan itu sendiri masih dilakukan oleh PT. Refined Bangka Tin (RBT) hingga saat ini.

Kegiatan penambangan timah tentunya memiliki dampak secara langsung kepada ekologi sekitar. Dampak lingkungan yang cukup terlihat jelas yakni dengan adanya galian bekas tambang atau yang sering disebut oleh masyarakat lokal dengan 
sebutan "kolong" atau "lubang camoy". Kolong atau lubang camoy yang begitu banyak menjadi sebuah konsekuensi logis akibat dari adanya kegiatan penambangan. Selain itu, kegiatan penambangan timah inkonvensional memberikan dampak negatif terhadap lingkungan dan kondisi sosial masyarakat (Erwana et al., 2016).

Kegiatan penambangan dan hadirnya perusahaan tambang juga tidak luput hadirnya konflik di dalam sebuah tatanan masyarakat. Konflik-konflik ini biasanya terjadi dalam beberapa aspek, yakni biasanya tidak jarang masyarakat mendapatkan dampak buruk dari aktivitas pertambangan. Banyak kasus ketidakpuasan publik yang bermunculan, baik yang berkaitan dengan pencemaran lingkungan, serta eksploitasi besar-besaran terhadap energi dan sumber daya alam (SDA) yang menyebabkan kerusakan alam, hingga berujung pada kekerasan (Ramadhan et al., 2016).

Secara administratif Desa Penyamun terletak di Kabupaten Bangka Kecamatan Pemali, Provinsi Kepulauan Bangka Belitung. Desa ini relatif mudah dijangkau dari pusat Kota Sungailiat, dan hanya berjarak kurang lebih $45 \mathrm{~km}^{2}$ dari ibukota provinsi. Jumlah penduduk Desa Penyamun sebanyak 4.125 jiwa terdiri dari 2.135 jiwa lakilaki dan 1.990 jiwa perempuan pada tahun 2019. Desa Penyamun terdiri dari 22 RT dan 4 Dusun meliputi, Penyamun, Tutut, Mentabak, dan Keceper. Penduduknya sendiri terdiri dari beragam agama, etnis dan ras. Mayoritas masyarakat setempat selain sebagai penambang banyak pula yang berkebun seperti lada, karet dan sawit.

Pertambangan yang ada di Desa Penyamun dikelola oleh PT. Renifed Bangka Tin (RBT). RBT ini merupakan Perusahaan yang berkomitmen untuk melakukan program reklamasi berkelanjutan dengan menanam tanaman hutan dan tanaman pangan yang bernilai ekonomis sekaligus aman untuk dikonsumsi, guna merevitalisasi atau mengembalikan fungsi tanah yang sudah tidak produktif akibat pertambangan yang dilakukannya. Program reklamasi berkelanjutan RBT ini juga bertujuan mengajarkan cara bertani dan memberikan sumber penghasilan alternatif bagi kehidupan masyarakat di sekitar wilayah pertambangan.

Sebagai salah satu produsen terbesar di Indonesia yang menjalankan program reklamasi berkelanjutan, RBT berkomitmen akan mengembalikan lahan seluas $50 \mathrm{Ha}$ bekas pertambangan untuk digunakan sebagai kawasan konservasi lahan, agrikultur, agrowisata, dan eco-education yang mengajarkan cara bertani serta menjaga lingkungan yang baik pada masyarakat setempat. RBT juga ingin memastikan bahwa 
semua aktivitas pertambangan dikelola dengan mengedepankan kepentingan lingkungan. Informasi yang diperoleh melalui www.rbt.co.id bahwa upaya ini sebagai bukti komitmen RBT untuk menjaga kelestarian lingkungan dan mendukung upaya pemerintah untuk mencegah perubahan iklim.

Upaya restorasi lahan pasca tambang yang menjadi kewajiban perusahaan tambang perlu dilakukan, dan biasanya aspek yang cukup berpengaruh dalam upaya reklamasi ini ialah pemerintah, pihak perusahaan tambang, dan masyarakat. Tetapi dalam pengelolaan pembangunan biasanya masyarakat selalu menjadi korban ketimbang penikmat pembangunan itu sendiri, dan tidak jarang mengakibatkan munculnya konflik antara perusahaan tambang dan masyarakat. Sehingga, aspek dari kelompok masyarakat ini perlu terlibat dan diberdayakan lebih intensif. Agar masyarakat sendiri merasa diposisikan sejajar dengan kelompok lainnya dalam upaya reklamasi pembangunan kawasan pasca tambang (Iswahyudi et al., 2013).

Oleh karena itu, kondisi inilah yang menjadi latar belakang kenapa penelitian ini perlu dilakukan. Penelitian ini berangkat dari rasa penasaran peneliti yakni; bagaimana pengelolaan restorasi pasca tambang yang dilakukan oleh PT. RBT di Desa Penyamun? dan bagaimana keterlibatan masyarakat lokal dalam proses restorasi tersebut? Sehingga hasil dari penelitian ini menjawab kedua pertanyaan tersebut yang berkaitan dengan pengelolaan restorasi pasca tambang dan keterlibatan masyarakat lokalnya.

\section{METODE PENELITIAN}

Metode yang digunakan dalam tulisan ini menggunakan pendekatan kualitatif deskriptif. Pada dasarnya penelitian dilakukan bertujuan untuk memperoleh jawaban atau penjelasan yang sebenar-benarnya terkait dengan suatu fenomena yang diteliti. Namun untuk memperoleh penjelasan dari sesuatu yang ingin diteliti maka dibutuhkan informasi atau data-data yang akurat dan terpercaya. Ciri dari jenis pendekatan kualitatif menekankan pada penggalian, penjelasan, dan pendeskripsian pengetahuan secara etik, emik, dan holistik (Creswell, 2016). Sumber data yang didapatkan yaitu data primer dan data sekunder. Data primer yang didapatkan dilakukan dengan pendekatan wawancara dengan masyarakat setempat dan Focus Group Discussion (FGD) dengan para pemangku kepentingan di Desa Penyamun. 
Sedangkan, untuk data sekunder didapatkan dengan melalui penelusuran buku dan hasil-hasil penelitian terdahulu.

Narasumber yang ada dalam penelitian ini meliputi masyarakat dan juga tokoh penting di Desa Penyamun seperti : Bapak Susanto, Bapak Ismail, Bapak Saiful,Ibu Fatmawati yang merupakan masyarakat setempat dan ada juga sekaligus bekerja sebagai petani di lahan reklamasi PT. Refined Bangka Tin (RBT). Kemudian ada juga pemangku kepentingan dari Desa Penyamun dan perwakilan dari PT. Refined Bangka Tin yakni: Bapak Agus, Kepala Desa Penyamun, Bapak Suwarno, merupakan karyawan PT. RBT yang khusus menjadi bidang pengawasan reklamasi di lahan reklamasi PT. RBT Desa Penyamun.

\section{PEMBAHASAN}

\section{Upaya Restorasi Lahan Pasca Tambang oleh PT. Refined Bangka Tin (RBT)}

Restorasi merupakan pengembalian atau pemulihan ke keadaan semula, dalam proses reklamasi lahan bekas tambang di Desa Penyamun kabupaten Bangka dilakukan oleh PT. RBT. RBT menjadi salah satu produsen timah batangan (tin ingot) yang terbesar di Indonesia. Di lantai produksi RBT dilengkapi fasilitas yang disempurnakan guna menjaga kualitas dan mendukung lingkungan hijau sehat (Green For Good).

Perbincangan mengenai permasalahan timah pasti berujung pada ekologi lingkungan, mengingat pertambangan timah memiliki dampak bagi lingkungan. Dapat kita lihat pertambangan yang telah dibuka sejak tahun 2002 hingga berakhir di tahun 2008 ini meninggalkan sebuah lahan gersang dan beberapa lubang-lubang yang disebut oleh masyarakat setempat sebagai kolong. Tidak hanya di daerah Penyamun tetapi tersebar di berbagai daerah di Pulau Bangka, sehingga permasalahan lingkungan seperti inilah yang menyebabkan masyarakat kurang mempercayai penambangan yang dilakukan oleh perusahaan-perusahaan, dan lebih bersikap kontra terhadap aktivitas tambang.

Melalui PT. RBT penanganan terhadap lahan-lahan bekas tambang akan dilakukan upaya restorasi dengan melakukan program reklamasi berkelanjutan yakni Green For Good. Ini merupakan program konservasi tanah untuk menghidupkan kembali fungsi tanah yang dinyatakan tidak produktif lagi dikarenakan aktivitas 
tambang sebelumnya. Pada akhir tahun 2017 PT. RBT berinisiatif melaksanakan program reklamasi berkelanjutan di lahan tambang Desa penyamun. Dengan melakukan penanaman tanaman hutan dan tanaman pangan yang bernilai ekonomis bagi masyarakat setempat. Penanaman tanaman yang bernilai ekonomis ini menjadi sebuah riset proyek yang dilakukan oleh PT. RBT sebagai bentuk restorasi kawasan pasca tambang yang memang difokuskan pada bidang pertanian.

Sebagai upaya pemulihan kembali lahan bekas galian tambang, sebanyak 50 hektar lahan yang akan dilakukan konservasi oleh PT. RBT. Berdasarkan informasi di lapangan bahwa, sebanyak 2,4 Hektare tanaman multi kutural, 7 hektar untuk untuk tanaman komersil yakni tanaman forestri atau dengan nama lain sengon laut yang bertujuan mengembalikan unsur hara tanah, 1 hektar untuk fasilitas jalan, 0,6 untuk tanaman musiman terdiri dari kelapa, jambu air, mangga, semangka, nanas dan lain sebagainya yang tidak mengandung logam berat. Saat ini lahan yang direklamasi hanya 12 hektare saja, dikarenakan ini sebagai bahan percobaan terlebih dahulu, jika nanti reklamasi 12 hektar ini berhasil maka 38 hektar sisasnya baru akan dilakukan reklamasi lebih lanjut.

Reklamasi lebih lanjut akan dikelola oleh koperasi desa yang dibentuk oleh PT. RBT, yaitu koperasi pertanian penyamun lestari. Kemudian status lahan akan berubah menjadi hak guna usaha (HGU) dan memberikan penguasaan pengelolaan kepada koperasi tersebut. Hal ini dikarenakan di Desa Penyamun sendiri belum ada koperasi untuk membantu pengelolaan hasil pertanian di lahan reklamasi maupun pengelolaan reklamasi tersebut. Meskipun koperasi ini dibentuk oleh PT. RBT tetapi anggota koperasi mayoritasnya adalah masyarakat Desa Penyamun sendiri. Sehingga nantinya yang akan mengelola lebih lanjut reklamasi bekas tambang ini secara tidak langsung adalah masyarakat setempat.

Dalam melakukan upaya restorasi ini pihak PT. RBT telah melewati beberapa proses. Proses pertama jelas terlebih dahulu melakukan analisis dampak lingkungannya (AMDAL) yang juga difasilitasi oleh pemerintah. Kemudian mempersiapkan lahan yang akan ditanami oleh tanaman yang bernilai ekonomis. Selanjutnya dalam upaya pemeliharaan tumbuhan yang ada di lahan reklamasi ini pihak PT. RBT menggunakan beberapa bahan-bahan yang dipercaya menjaga kesuburan tanaman yang ditanam yakni, 25\% menggunakan kompos organik, 25\% 
TG atau Tai Gajah yang dikirim langsung dari way kambas, 25\% menggunakan polinter bag, dan 25\% menggunakan produk RBT sendiri yakni Super Natural Nutrition (SNN) dan Sari Alam Nusantara (SAC).

Tanaman yang telah diberikan bahan-bahan yang berguna menjaga kesuburan tanah kemudian dirawat oleh petani dari PT. RBT yang sekaligus juga sebagai masyarakat lokal setempat. Untuk hasilnya, dari mulai ditanamkannya tanaman komersil ini sejak tahun 2018 hingga sekarang belum memberikan hasil yang banyak. Hanya saja tanaman-tanaman yang terus menghasilkan atau tidak tergantung usia tanaman seperti cabai, semangka dan nanas biasanya sudah dapat dipetik hasilnya dengan cara dijual di pasar setempat atau sebagian dikonsumsi sendiri.

Kemudian ketika penataan ruang lahan yang dikelola dirasa sudah tepat dan telah menghasilkan beberapa jenis tanaman yang bernilai ekonomis, maka areal reklamasi akan dibuat menjadi sebuah agrowisata. Agrowisata ini akan melibatkan masyarakat melalui koperasi penyamun lestari dan bekerjasama dengan Dinas Pertanian Kabupaten Bangka.

\section{Pandangan Masyarakat, dan Keterlibatan Masyarakat dalam Upaya Restorasi Lahan Pasca Tambang Desa Penyamun}

Desa Penyamun, Kecamatan Pemali Kabupaten Bangka merupakan salah satu area bekas pertambangan timah yang ada di Provinsi Kepualauan Bangka Belitung. Lahan galian bekas pertambangan timah ini tentu dilakukan upaya pemanjaan lahan agar dapat digunakan kembali dan memberikan kebermanfaatan yang berkelanjutan. Dalam hal ini, masyarakat lokal menjadi salah satu bagian penting dalam proses pemanjaan lahan bekas galian timah.

Berdasarkan wawancara yang dilakukan kepada masyarakat dan juga kepala Desa Penyamun bahwa, masyarakat sudah mengetahui jika galian bekas tambang yang dilakukan oleh PT. RBT akan dilakukan upaya pemulihan lahan. Masyarakat Desa Penyamun sebagaian besar sudah mengetahui arah dan kebijakan rencana reklamasi pada lahan bekas tambang di desa mereka. Arah dan kebijakan reklamasi yang dilakukan oleh pihak perusahaan tersampaikan melalui perundingan dari pihak perusahaan kepada pemerintah desa. 
Upaya restorasi yang dilakukan tidak terlepas dari prinsip-prinsip restorasi ekologi. Masyarakat ekologi restorasi atau atau Society of Ecological Restoration mengartikan ekologi restorasi sebagai upaya yang disengaja untuk melakukan percepatan pemulihan suatu ekosistem. Menurut Sutomo (2011) tujuan dari ekologi restorasi ini meliputi 1 . merestorasi situs terlokalisasi yang terganggu atau rusak seperti bekas areal pertambangan, 2. untuk meningkatkan kemampuan produktivitas di lahan produksi yang terdegradasi, 3. Memperkaya nilai-nilai konservasi alam di areal lanskap yang dilindungi, 4. Merestorasi proses-proses ekologis di dalam suatu lanskap yang luas. Selain itu juga, restorasi ekologi menaungi semua dimensi tidak hanya ekologi restorasi saja, tetapi juga dari sisi kajian sosial, ekonomi, dan kebijakan untuk mencapai tujuannya.

Dalam upaya restorasi kawasan pasca tambang timah di Desa Penyamun, sikap masyarakat setempat terhadap reklamasi oleh PT. RBT ini juga awalnya mengalami pro dan kontra. Dimana masyarakat yang pro (setuju) dengan reklamasi ini melihat bahwa reklamasi yang dilakukan oleh PT. RBT selain mengatasi permasalahan lingkungan tetapi juga membantu pemerintah dan masyarakat dalam mengatasi pengangguran dan sulitnya mencari pekerjaan pada saat kondisi sekarang. Apalagi pihak RBT membuka seluas-luasnya bagi masyarakat yang ingin menanam di lahan bekas tambang yang menjadi lahan reklamasi. Dengan adanya reklamasi ini diharapkan bisa memberikan kesempatan kepada masyarakat setempat agar bisa bekerja yang nantinya dapat membantu meningkatkan perekonomian masyarakat.

Sedangkan untuk masyarakat yang kontra (tidak setuju) pada awalnya melihat bahwa reklamasi oleh PT. RBT bisa menyebabkan berkurangnya lahan masyarakat setempat. Berdasarkan informasi dari pemerintah desa, masyarakat menaruh kecurigaan terhadap PT. RBT terkait lahan yang diambil, dan ada kecemburuan sosial terkait lahan masyarakat. Tetapi seiring waktu sikap masyarakat yang awalnya menolak kemudian beralih setuju dengan reklamasi oleh PT. RBT karena memberikan dampak positif juga terhadap masyarakat Desa Penyamun itu sendiri.

Dampak positif yang dapat diterima oleh masyarakat ialah, pihak perusahaan melibatkan masyarakat dalam upaya pemulihan lahan. Hal ini dibuktikan dengan masyarakat umum yang bukan termasuk ke dalam pegawai perusahaan dibebaskan menanam tanaman lokal seperti, cabai, tomat, kacang panjang dan tanaman sayuran 
lokal lainnya. Selain itu juga pihak perusahaan ikut terlibat dalam perkembangan desa dengan terlibatnya perusahaan terhadap pembuatan dan perbaikan jalan yang ada di Desa Penyamun.

Menurut laporan dari pekerja yang ada di PT. RBT, dulu pegawainya berjumlah 14 orang namun kini menjadi 7 orang. Para pekerja sebagai petani perusahaan ini berasal dari masyarakat lokal setempat. Pekerja di lahan reklamasi tersebut selain sebagai petani mereka memiliki usaha sampingan yaitu ternak lele yang dilakukan di lahan reklamasi juga, yang mana ternak lele ini bukan dikelola untuk perusahaan, tetapi untuk petani itu sendiri. Hal ini dilakukan oleh para pekerja agar lahan-lahan yang belum ditanamkan oleh tanaman dapat berguna dan memberikan manfaat kepada para pekerja yang juga sekaligus sebagai masyarakat lokal.

Selain para pekerja perusahaan yang melakukan kegiatan penanaman, masyarakat lokal pun diberikan kebebasan untuk menanam tanaman lokal di lahan reklamasi. Tentunya dengan diberikannya izin kepada masyarakat lokal untuk dapat melakukan aktivitas bercocok tanam ini memerikan ruang kepercayaan dari masyarkat kepada pihak perusahaan PT. RBT, karena memberikan ruang kepada masyarakat setempat untuk ikut andil dalam mengelola lahan pasca tambang tersebut dengan cara melakukan kegiatan cocok tanam dan juga peternakan lele. Disinilah letak keterlibatan masyarakat lokal untuk terlibat dalam pengelolaan lahan reklamasi yang mana lahan ini kelak akan dikelolah oleh koperasi desa secara penuh.

Dalam proses pemasaran hasilnya terkadang ada pihak tengkulak yang datang untuk membeli hasil pertanian mereka, baik petani dari pegawai perusahaan ataupun petani dari masyarakat lokal. Tetapi tengkulak tersebut bukan berasal dari desa mereka melainkan dari luar desa, dan pihak pemerintahan desa berencana untuk membuat pasar desa agar mempermudah pemasaran yang dilakukan oleh masyarakat itu sendiri. Sehingga dari pemasaran tersebut perputaran uang di pasar desa akan menunjang perekonomian masyarakat lokal.

Sejauh ini masyarakat Desa Penyamun secara keseluruhan mendukung kegiatan reklamasi yang dilakukan di desa mereka, baik itu pembentukan koperasi oleh pihak PT. RBT hingga upaya peremajaan lahan bekas tambang. Seperti yang dijelaskan sebelumnya, sejauh ini upaya restorasi di lahan pasca tambang PT. RBT memberikan dampak positif bagi masyarakat. Selain meningkatkan produktifitas dan 
meningkatkan perekonomian masyarakat juga dapat terlihat dari perbaikan jalan yang ada di desa mereka. Kemudian pada setiap hari lebaran idul adha pihak RBT memberikan sapi untuk dapat diqurbankan, dan juga memberikan sembako kepada masyarakat setempat. Sehingga hal ini tentunya ada simbiosis mutualisme dari kedua pihak terkait upaya restorasi lahan pasca tambang timah di Desa Penyamun ini.

\section{KESIMPULAN}

Dalam upaya reklamasi yang dilakukan oleh PT. RBT ini jika dilihat dari sudut pandang etika lingkungan antroposentrisme, yang mana menurut antroposentrisme ini sendiri adalah manusia sebagai pusatnya, manusia memiliki kekuasaan atas lingkungannya. Dengan begitu manusia yang menentukan tatanan ekosistem dan dalam kebijakan yang diambil dalam kaitannya dengan alam, baik secara langsung maupun tidak langsung (Suka, 2012). Sehingga menurut pandangan antroposentrisme, kegiatan yang dilakukan oleh manusia untuk mengeksploitasi tambang timah di Desa Penyamun yang kemudian dilakukan upaya reklamasi kembali merupakan bentuk kekuasaan manusia atas lingkungannya.

Dalam kaitan restorasi ekologi bahwa, proses restorasi kawasan pasca tambang timah di Desa Penyamun dan keterlibatan masyarakat lokalnya memiliki tujuan untuk meningkatkan kemampuan produktivitas di lahan produksi yang terdegradasi. Ini dilakukan dengan cara memanfaatkan lahan bekas tambang sebagai lahan pertanian yang bernilai ekonomis melalui program lingkungan hijau sehat (Green For Good), yang pada akhirnya bertujuan menciptakan lanskip ekowisata yang dikelola dari masyarakat melalui koperasi penyamun lestari.

Kemudian aktivitas reklamasi yang dilakukan oleh PT. RBT memiliki manajemen pengelolaan tanah bekas galian timah yang cukup baik, hal ini dibuktikan dengan variasi spesies tanaman yang dilakukan di bekas lahan galian. Selain itu juga, pelibatan masyarakat terhadap upaya pemulihan lahan dilakukan dengan optimal, sehingga ikut menyumbang tingkat produktivitas masyarakat dan juga membantu secara ekonomi bagi masyarakat setempat. Terlebih membuka peluang kepercayaan yang besar dari masyarakat lokal kepada pihak perusahaan. 


\section{DAFTAR PUSTAKA}

Anonim. Profil Perusahaan PT.RBT. (https://www.rbt.co.id/companyprofile/company-overview).

Bustami Rahman, Dwi Haryadi, D. 2011. Menyoal Pertimahan di Babel (Beberapa Cerita dan Gagasan). KHOMSA Kalangan KD III.

Creswell, J. W. 2016. Research Design (Pendekatan Metode Kualitatif, Kuantitatif, dan Campuran). In Terjemahan Bahasa Indonesia. https://doi.org/10.1002/t1.20234

Erwana, F., Dewi, K., \& Rahardyan, B. 2016. Kajian Dampak Penambangan Timah Inkonvensional Terhadap Lingkungan Dan Sosial Ekonomi Masyarakat (Studi Kasus: Kabupaten Bangka Barat Provinsi Kepulauan Bangka Belitung). Jurnal Tehnik Lingkungan. https://doi.org/10.5614/j.t1.2016.22.2.4

Harahap, F. R. 2016. Restorasi Lahan Pasca Tambang Timah Di Pulau Bangka. Society. https://doi.org/10.33019/society.v4i1.36

https://www.rbt.co.id/company-profile/company-overview

Iswahyudi, M., Wahyu, Shiddiq, M., \& Erhaka, M. E. 2013. Masyarakat Lokal Dan Program Reklamasi Lahan Bekas Tambang Di Desa Banjar Sari Kecamatan Angsana. Enviro Scienteae.

Peraturan pemerintah Republik Indonesia No. 78 tahun 2010. Tentang Reklamasi dan Pasca Tambang. http://ditjenpp.kemenkumham.go.id/arsip/ln/2010/pp782010bt.pdftjenpp.kemenkumham.go.id.

Ramadhan, D. T., Budimanta, A., \& Soelarno, S. W. 2016. Resolusi Konflik Antara masyarakat lokal dengan perusahaan pertambangan (studi kasus: kecamatan naga juang, kabupaten mandailing natal, provinsi sumatera utara). Jurnal Ilmu Lingkungan. https://doi.org/10.14710/jil.12.2.92-104

Sutomo. 2011. Restorasi Ekologi, http://u.lipi.go.id/1321050669..

Suka, I. G. 2012. Teori Etika Lingkungan, Antroposentrisme, Ekofeminisme, Ekosentrisme. Udayana University Press. 